\title{
Liquid Chromatography Electrochemical Determination of Nicotine in Third-Hand Smoke
}

\author{
Xianglu Peng, Danielle Giltrow, Paul Bowdler and Kevin C. \\ Honeychurch $^{*}$
}

Centre for Research in Biosciences, Faculty of Health \& Life Sciences, University of the West of England, Frenchay Campus, Coldharbour Lane, Bristol, BS16 1QY, UK, ”kevin.honeychurch@uwe.ac.uk

\section{Abstract}

Third-hand smoke (THS) can be defined as the contamination of surfaces by second-hand smoke. This residue can form further pollutants which can be re-suspended in dust or be re-emitted into the gas phase. THS is a complex mixture and as a result studies have focused on nicotine as a marker of THS, it being the most abundant and indicative organic compound deposited. In this present study, the extraction of dust wipe samples and the subsequent chromatographic conditions required for the separation of nicotine by liquid chromatography with electrochemical detection were investigated and optimised. The optimum chromatographic conditions were identified as a $150 \mathrm{~mm}$ $x 4.6 \mathrm{~mm}, 5 \mu \mathrm{m} \mathrm{C}_{18}$ column with a mobile phase consisting of $65 \%$ methanol, $35 \% \mathrm{pH} 820 \mathrm{mM}$ phosphate buffer. Hydrodynamic voltammetry was used to optimise the applied potential which was identified to be $+1.8 \mathrm{~V}$ (vs. stainless steel). Under these conditions, a linear range for nicotine of 13 to $3240 \mu \mathrm{g} / \mathrm{L}(0.26 \mathrm{ng}-65 \mathrm{ng}$ on column) was obtained, with a detection limit of $3.0 \mu \mathrm{g} / \mathrm{L}(0.06 \mathrm{ng}$ on column) based on a signal-to-noise ratio of three. Dust wipe samples were extracted in methanol with the aid of sonication. Mean recoveries of $98.4 \%$ (\% CV $=7.8 \%$ ) were found for dust wipe samples spiked with $6.50 \mu \mathrm{g}$ of nicotine. Musk ketone, urea and stearic acid were found not to interfere. Communal entrance ways were found to be contaminated with THS nicotine levels of between 66.8 and $156 \mu \mathrm{g} / \mathrm{m}^{2}$.

Keywords: Third-hand smoke; dust wipe; nicotine; liquid chromatography electrochemical detection; voltammetry; amperometry. 


\section{Introduction}

Nicotine (i) is a pyridine alkaloid found in several species of fungi and plants. The most common source of nicotine is the plant Nicotiana tabacum which is commercially grown in many countries and processed into tobacco which is either chewed or smoke to release the nicotine present. Nicotine acts on the central nervous system causing an elevation of mood in the smoker and causing the individual to feel more relaxed. This effect is one of the features desirable to smokers resulting in their continued use of nicotine containing tobacco products. Nicotine is reported to equate to between $6.17 \mathrm{mg}$ and $28.86 \mathrm{mg}$ per cigarette and up to $50.89 \mathrm{mg} / \mathrm{g}$ in pipe tobacco [1] and it is the most abundant chemical found in tobacco smoke [2], making it a useful marker for the analysis of tobacco smoke in environmental [3] and biological samples [4,5].

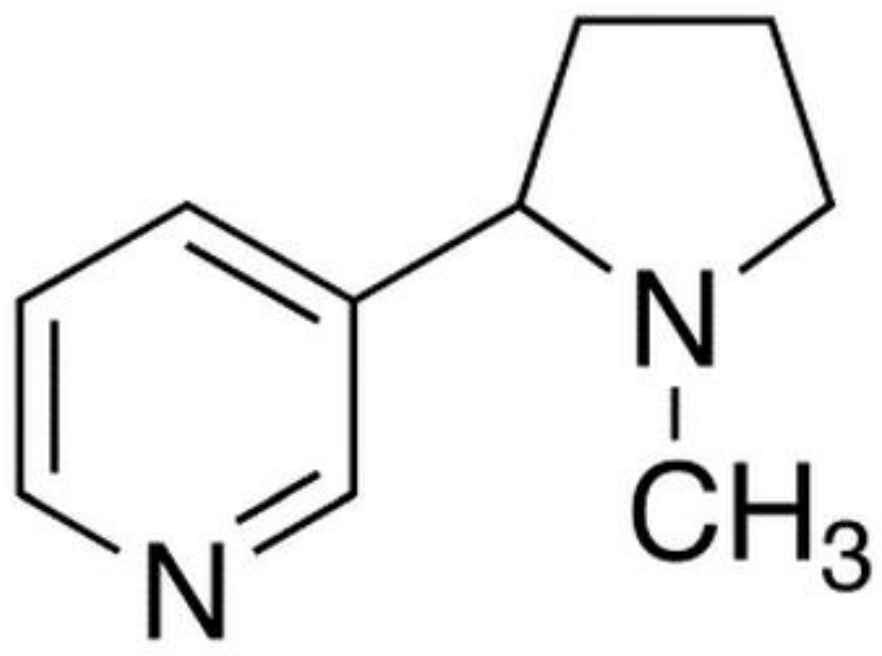

(i)

Recent research [6-8] has demonstrated that not only are individuals at risk from smoking itself or second hand smoke produced, but they are also exposed to what is referred to as third hand smoke (THS). THS is formed from tobacco smoke or vapour and remains 
deposited after the smoking has ceased. Studies have found that nicotine and other compounds can be found in house dust, cars and hotel rooms and on surfaces [6]. The deposited nicotine can react with pollutants, such as nitrous acid and ozone to form toxic and potentially mutagenic and cytotoxic compounds known as tobacco-specific nitrosamines (TSNAs) $[7,8]$ which can be reemitted back into the environment by degassing or through movements of dust [6].

A number of different analytical methods have been utilised for the determination of nicotine in THS [9-21]. Nicotine has been determined in several different sample matrices such as toenails [22] and hair [23-26] utilising the liquid chromatography with electrochemical detection (LC-ED) method developed by Mahoney and Al-Delaimy [27], however to our knowledge, there have been no other reports on its determination by LC-ED. LC-ED offers a number of advantages, as it is both a sensitive and economic approach as has been demonstrated in number of previous reviews and monographs focused on its theory and application [28-30]. Table 1 describes earlier reported liquid chromatographic and electrophoretic approaches using electrochemical detection for the determination of nicotine. Previous reverse phase LC-ED approaches require mobile phase containing ion pairing agents and low concentrations of organic modifier; situations which can lead to stationary phase de-wetting and long conditioning times resulting in poor separation and overall analytical performance. These approaches have also utilised multiple electrode detection systems requiring complex dedicated equipment for their control and application. Our present report represents the first report of LC-ED using the much simpler and economic approach of single electrode amperometric detection [31]. Our system requires only a standard potentiostat and a commercially available thin layer cell for its 
implementation; notably cheaper and easier to maintain than dedicated electrochemical detector systems. Our approach also allows for overall shorter run times and preconditioning times as we have avoided the use of ion-pairing reagents.

In the first part of this investigation we examined the electrochemical behaviour of nicotine by cyclic voltammetry, examining the effect of both scan rate and $\mathrm{pH}$. The chromatographic conditions were then optimised and we then used hydrodynamic voltammetry to identify the optimum applied potential for its determination by LC-ED. The possibility of extracting nicotine from dust wipes was then investigated, and a number of real samples were examined using the optimised method. 


\begin{tabular}{|c|c|c|c|c|}
\hline Technique & Linear Range & Limit of Detection & Comments & Ref \\
\hline $\begin{array}{l}\text { Liquid chromatography with } \\
\text { dual electrochemical } \\
\text { detection at a porous } \\
\text { graphite electrode. }\end{array}$ & $\begin{array}{l}4 \text { to } 640 \mathrm{ng} / \mathrm{mg} \\
\text { of human hair. }\end{array}$ & $\begin{array}{l}0.05 \mathrm{ng} \text { for } 2 \mathrm{mg} \text { of } \\
\text { human hair. }\end{array}$ & $\begin{array}{l}\text { Determination of nicotine in children's hair using } 2 \text {-phenylimidazole as an } \\
\text { internal standard. The voltage settings for the conditioning cell and } \\
\text { detectors } 1 \text { and } 2 \text { were }+0.6,+0.6 \text { and }+0.9 \mathrm{~V} \text { respectively. }\end{array}$ & {$[27]$} \\
\hline $\begin{array}{l}\text { Liquid chromatography with } \\
\text { dual electrochemical } \\
\text { detection at a porous } \\
\text { graphite electrode. }\end{array}$ & $0.2 \mathrm{ng}$ to $5 \mu \mathrm{g}$ & & $\begin{array}{c}\text { Dual electrode detection. Guard cell }=+1.0 \mathrm{~V} \text {, detector } 1=-0.5 \mathrm{~V} \text { and } \\
\text { detector } 2=+0.75 \mathrm{~V} \text {. Reverse-phase } \mathrm{C}_{18} \text { stationary phase. Mobile phase } \\
\text { primary buffer } 92.5 \% 2 \mathrm{mM} \mathrm{NaH} \mathrm{PO}_{4} \text { containing } 0.25 \mathrm{mM} \text { Na octyl sulphate; } \\
\text { secondary buffer } 7.5 \% \text { methanol-acetonitrile }(3: 1) \text { adjusted to pH } 3.0 \text { with } \\
\mathrm{H}_{3} \mathrm{PO}_{4} .\end{array}$ & {$[32]$} \\
\hline $\begin{array}{l}\text { Liquid chromatography with } \\
\text { dual electrochemical } \\
\text { detection. }\end{array}$ & 0.2 to $1.0 \mathrm{ng}$ & & $\begin{array}{c}\text { Dual glassy carbon electrode, detection potential }+0.75 \mathrm{~V} \text {. Mobile phase of } 2 \\
\mathrm{mM} \mathrm{NaH}_{2} \mathrm{PO}_{4}, 0.25 \mathrm{mM} \text { sodium octyl sulphate, } 5 \% \text { organic modifier } \\
\text { (acetonitrile : methanol, 3:1 by volume). Stationary phase } \mathrm{C}_{18} \text {. Samples of } \\
\text { nicotine in dog plasma analysed after protein precipitation and diluted in } \\
\text { mobile phase. }\end{array}$ & [33] \\
\hline $\begin{array}{c}\text { Micellar liquid } \\
\text { chromatography with } \\
\text { electrochemical detection }\end{array}$ & 0.03 to $2 \mu \mathrm{g} / \mathrm{mL}$ & $4 \mathrm{ng} / \mathrm{mL}$ & $\begin{array}{l}\text { Nicotine in chewing gum, dermal patches, tobacco and serum samples. } \\
\text { Mobile phase of SDS } 0.15 \mathrm{M}-6 \%(\mathrm{v} / \mathrm{v}) \text { pentanol-0.01M NaH} \mathrm{PO}_{4}(\mathrm{pH} 6)- \\
0.001 \mathrm{M} \mathrm{KCl} \text {. Applied potential +0.8 V. }\end{array}$ & [34] \\
\hline Capillary electrophoresis. & $\begin{array}{c}0.01 \text { to } 2.0 \\
\mu \mathrm{g} / \mathrm{mL}\end{array}$ & $2 \mathrm{ng} / \mathrm{mL}$ & $\begin{array}{c}\text { Detection at }+0.95 \mathrm{~V} \text { at a pencil carbon disc working electrode. Separation } \\
\text { by capillary electrophoresis: fused-silica capillary, } 25 \mu \mathrm{m} \text { internal diameter } \times \\
65 \mathrm{~cm} \text {; working electrode: } 0.3 \mathrm{~mm} \text { diameter carbon disc electrode; running } \\
\text { buffer: PBS, BB, and Tris- } \mathrm{HCl} \text { solution with pH of } 8.0,60 \mathrm{mM} \text {. Separation } \\
\text { voltage: } 18 \mathrm{kV} \text {. Injection: } 10 \mathrm{~s} / 18 \mathrm{kV} \text {. }\end{array}$ & [35] \\
\hline Capillary electrophoresis. & $\begin{array}{l}5.0 \times 10^{-7} \text { to } \\
1.0 \times 10^{-4} \mathrm{M}\end{array}$ & $5 \times 10^{-8} \mathrm{M}$ & $\begin{array}{c}\text { Detection potential of }+1.20 \mathrm{~V} \text { at a carbon fibre working electrode }(33 \mu \mathrm{m} \\
\text { diameter).40 mM phosphate buffer }(\mathrm{pH} 2.0) \text {, a sample injection time of } 10 \mathrm{~s} \\
\text { at } 10 \mathrm{kV} \text { and a separation voltage of } 16 \mathrm{kV} \text {. }\end{array}$ & [36] \\
\hline
\end{tabular}

Table 1. Liquid chromatography and electrophoresis electrochemical detection based methods for the determination of nicotine. 


\section{Experimental}

\subsection{Chemicals and Reagents}

All chemicals were obtained from Fisher (Loughborough, UK), unless otherwise stated. Deionised water was obtained from a Purite RO200 - Stillplus HP System, fitted with a Pur-1-te ion-exchanger (Purite Oxon., UK). A $20 \mathrm{mM}$ phosphate $\mathrm{pH} 8.0$ buffer was prepared by titration of a solution of 0.2 $\mathrm{M}$ trisodium phosphate, with $0.2 \mathrm{M}$ phosphoric acid and subsequent dilution. Primary stock solutions of nicotine (Sigma-Aldrich, Dorset, UK), were prepared by dissolving the required mass in acetonitrile to give a concentration of $10 \mathrm{mM}$. Working standards, for initial voltammetric studies, were prepared by dilution of the primary stock in sufficient water, acetonitrile and phosphate buffer, to give an overall concentration of $2 \mathrm{mM}$ nicotine in $10 \%$ acetonitrile $0.1 \mathrm{M}$ phosphate buffer. The surface-wipes were fabricated by cutting $10 \mathrm{~cm}^{2}$ squares from a roll of tissue (one ply, Jangro White Centrefeed, Pattersons, Bristol, UK). Standards for LC-ED analysis were made by dilution of the primary stock solution in mobile phase.

\subsubsection{High Performance Liquid Chromatography}

HPLC studies were undertaken using an Agilent 1100 HPLC system with a $250 \mathrm{~mm} \times 4.6 \mathrm{~mm}$ Hypersil Gold $\mathrm{C}_{18}, 5 \mu \mathrm{m}$ column connected to a 7125 valve manual injector fitted with a $20 \mu \mathrm{L}$ sample loop (Rheodyne, Cotati, USA). Sample extracts were determined using a mobile phase of $65 \%$ methanol, (Fischer, Far UV, HPLC grade) $35 \% 20$ mM pH 8.0 phosphate buffer at a flow rate of $1.0 \mathrm{~mL} / \mathrm{min}$.

\subsubsection{Electrochemical Detection}

The detector cell consisted of a two piece thin-layer cell, formed from an upper Kel-F block containing a GCE working electrode ( $3 \mathrm{~mm}$ diameter) and a bottom steel block serving as the pseudo-reference/counter electrode. Teflon gaskets were purchased from BAS, Congleton, Cheshire, UK. The inlet for the thin layer cell was connected directly to the outlet of the Agilent 1100 UV detector using a suitable PEEK connector and tubing. An Ivium CompactStat potentiostat (Ivium Technologies, The Netherlands) was used to control the potential at the thin layer cell at +1.8 V vs. the pseudoreference/counter stainless steel electrode (ss). Chromatograms were recorded 
using an Ivium CompactStat potentiostat (Ivium Technologies, The Netherlands) interfaced to a PC for instrument control and data acquisition.

\subsection{Cyclic Voltammetric Studies}

Cyclic voltammetry was undertaken using a $\mu$ Autolab potentiostat interfaced to a PC for data acquisition and control using the GPES software version 4.9. Cyclic voltammograms were initially recorded in plain solutions of $10 \%$ acetonitrile, $90 \%$ phosphate buffer and then in the same solution containing $2.0 \mathrm{mM}$ nicotine. A starting potential and an end potential of $0.0 \mathrm{~V}(\mathrm{vs}$. $\mathrm{Ag} / \mathrm{AgCl})$ was used, with a switching potential of $+1.5 \mathrm{~V}(v s . \mathrm{Ag} / \mathrm{AgCl})$. The effect of scan rate was studied over the range $20 \mathrm{mV} / \mathrm{s}$ to $200 \mathrm{mV} / \mathrm{s}$.

\subsection{Hydrodynamic Voltammetry}

Hydrodynamic voltammetry (HDV) was undertaken using an EG\&G Princeton Applied Research (Princeton, NJ) model 362 scanning potentiostat to control the applied potential. Chromatograms were recorded using a Siemens Kompenosograph X-T C1012 chart recorder. The hydrodynamic voltammetric behaviour of nicotine was investigated by injecting fixed volumes of a standard solution of nicotine and varying the applied potential between $+0.9 \mathrm{~V}$ and $+2.0 \mathrm{~V}$ (vs. ss) in $100 \mathrm{mV}$ steps. The hydrodynamic voltammogram was then constructed by plotting the recorded peak current against the applied potential. The optimum potential was determined from the position of the plateau on the hydrodynamic voltammogram.

\subsection{Dust Wipe Sampling}

Dust wipe samples were collected in a similar manner to that described previously [37]. The fronting of doors and windows facing onto entranceways were chosen for investigation. Dust wipe samples were obtained by wiping from the upper left corner of the sample area; in " $\mathrm{S}$ " shape manner, wiping from side-to-side whilst moving down the sample area. The exposed wipe was then folded in half, exposed side to exposed side and another " $\mathrm{S}$ " shape was made in the opposite direction wiping up and down instead of side-to-side. The folded wipe was placed in a glass vial, which was also used as the extraction vessel and sealed. A new pair of gloves was also used for each sample. A procedural 
blank was obtained by taking a tissue onsite but without sampling the surface. The area sampled was measured so that a comparison of concentration values $\left(\mu \mathrm{g} / \mathrm{m}^{2}\right)$ between different surfaces could be made.

\subsection{Sample Extraction and Analysis}

Five $\mathrm{mL}$ of methanol was added to the glass vessel containing the dust wipe sample. This was then sealed and the dust wipe extracted by sonication for 15 minutes at room temperature. A $200 \mu \mathrm{L}$ aliquot of this was taken and $100 \mu \mathrm{L}$ of $50 \mathrm{mM} \mathrm{pH} 8$ phosphate buffer added and investigated by liquid chromatography electrochemical detection.

\section{Results and Discussion}

\subsection{Cyclic Voltammetry}

Initial cyclic voltammetric studies were performed with a $2 \mathrm{mM}$ solution of nicotine, dissolved in 0.1 $\mathrm{M}$ phosphate buffer $\mathrm{pH} 10$, in the presence of $10 \%$ acetonitrile $(10 \mathrm{~mL})$. Figure 1 shows the cyclic voltammogram obtained at a GCE using a scan rate $(v)$ of $50 \mathrm{mV} / \mathrm{s}$. Two oxidation peaks were recorded, which we have designated as $\mathrm{O} 1$ and $\mathrm{O} 2$. There a number of different theories which have been postulated to explain the voltammetric behaviour of nicotine [32,38-42]. The majority of reports show nicotine to be oxidised in a single oxidation wave. However, in our present study, at $\mathrm{pH}$ values above $\mathrm{pH} 8$ two oxidation peaks are recorded, similar to the cyclic voltammetric behaviour reported by Cinková et al [39]. The effect of scan rate was studied at $\mathrm{pH} 2,4,6,8$ and 10, over the scan rate 10 to $200 \mathrm{mV} / \mathrm{s}$. For both oxidation processes peaks current $\left(i_{\mathrm{p}}\right)$ values were found to be proportional to the square of scan rate $\left(v^{1 / 2}\right)$, demonstrating diffusion controlled processes. The oxidation peak observable at $+1.6 \mathrm{~V}$ was concluded to results from the oxidation of common alkene [43] impurities present in the acetonitrile (i.e. acrylonitrile, acrolein, etc.), it being present in both the sample and the blank supporting electrolyte. Figure 2 shows the effect of $\mathrm{pH}$ on the cyclic voltammetric $i_{\mathrm{p}}$ for both oxidation peaks $\mathrm{O} 1$ and $\mathrm{O} 2$. The oxidation process $\mathrm{O} 2$ was found to independent of $\mathrm{pH}$ over the range studied. However, the more negative peak $\mathrm{O} 1$ shows a maximum at $\mathrm{pH} 8$ and as a result further investigations were made at this $\mathrm{pH}$. 


\subsection{Hydrodynamic Voltammetry}

Figure 3 shows the HDV obtained over the potential range +1.0 to $+1.9 \mathrm{~V}$ (vs. ss). The peak current response for nicotine was found to increase with increasing potential from $+1.0 \mathrm{~V}$ to $+1.7 \mathrm{~V}$ (vs. ss). At potentials more positive than this, between $+1.7 \mathrm{~V}$ and $+1.9 \mathrm{~V}$ (vs. ss), the response was found to plateau and become constant. Interestingly, under hydrodynamic conditions a single oxidation process is obtained, differing from the two separate electrochemical processes observable by cyclic voltammetry in quiescent solution (Figure 1). The oxidation mechanism would appear to be different under hydrodynamic conditions compare to that as obtained under quiescent conditions. Consequently, further LC ED studies were undertaken using an applied potential of $+1.8 \mathrm{~V}$ (vs. ss).

\subsection{Calibration, Limit of Detection, and Precision}

A linear range of $13 \mu \mathrm{g} / \mathrm{L}$ to $3240 \mu \mathrm{g} / \mathrm{L}\left(R^{2}=0.999\right)$ was obtained with an associated detection limit of $3.0 \mu \mathrm{g} / \mathrm{L}$, based on a signal to noise ratio of three. Dust wipes were spiked with $6.50 \mu \mathrm{g}$ nicotine $(\mathrm{n}=$ 5) and extracted using the procedure described. A mean recovery of $98.4 \%$ with a coefficient of variation of $7.8 \%$ was calculated.

\subsection{Studies of Possible Interferences}

A wide range of compounds could be potentially present in dust wipe samples resulting from cosmetics, soaps and human skin contact which could interfere with the determination of nicotine. In this present study we investigated; musk ketone, a nitroaromatic compound present detergents, perfumes and cosmetics, stearic acid, also present in cosmetics, soap, etc., the biological metabolite of nicotine, cotinine and urea, present in urine and to a lesser extent in sweat. None of these compounds were found to give any chromatographic response under the conditions employed and consequently did not interfere.

\section{Analytical Application}

The glass fronting of doors and windows facing onto entranceways were chosen for investigation. Figure 4 shows representative chromatograms obtained for extracted dust wipe samples. A well 
resolved peak for nicotine was obtained at a retention time of $185 \mathrm{~s}$. The levels found at the different sample locations are summarised in table 2 . The injection-to-injection time was only $210 \mathrm{~s}$ including a 100 s equilibration time.

\begin{tabular}{|c|c|}
\hline Sample & Nicotine, $\mu \mathrm{g} / \mathbf{m}^{2}$ \\
\hline 1 & 110 \\
\hline 2 & 150 \\
\hline 3 & ND \\
\hline 4 & 66.8 \\
\hline 5 & 156 \\
\hline
\end{tabular}

Table 2. Nicotine levels obtained for dust-wipe samples. ND = not detected.

\section{Conclusions}

A method using LC-ED has been successfully developed for the determination of trace levels of nicotine in THS dust wipe samples. The chromatographic separation is achieved using a $\mathrm{C}_{18}$ reversed phase column in conjunction with a methanol-phosphate buffer based mobile phase. Amperometric detection using an applied potential of $+1.8 \mathrm{~V}$ (vs. ss) was employed and well-resolved peak free from interferences was obtained with a retention time of only $185 \mathrm{~s}$. This is an improvement on our previously reported liquid chromatographic method utilising UV detection [37] as it is nearly twice as fast, is more selective and exhibits a better theoretical limit of detection. In this investigation levels of nicotine of between 66.8 to $156 \mu \mathrm{g} / \mathrm{m}^{2}$ were found, comparable to those we previously reported [37]. The developed method is more economic and simpler compared to LC/MS and related approaches, but has been shown to be able to determine levels comparable to those reported by other techniques $[10,11,20]$.

\section{Acknowledgements}

We are grateful to the University of the West of England, UK for funding. Mr Kevin Sudlow is thanked for his technical assistance. 


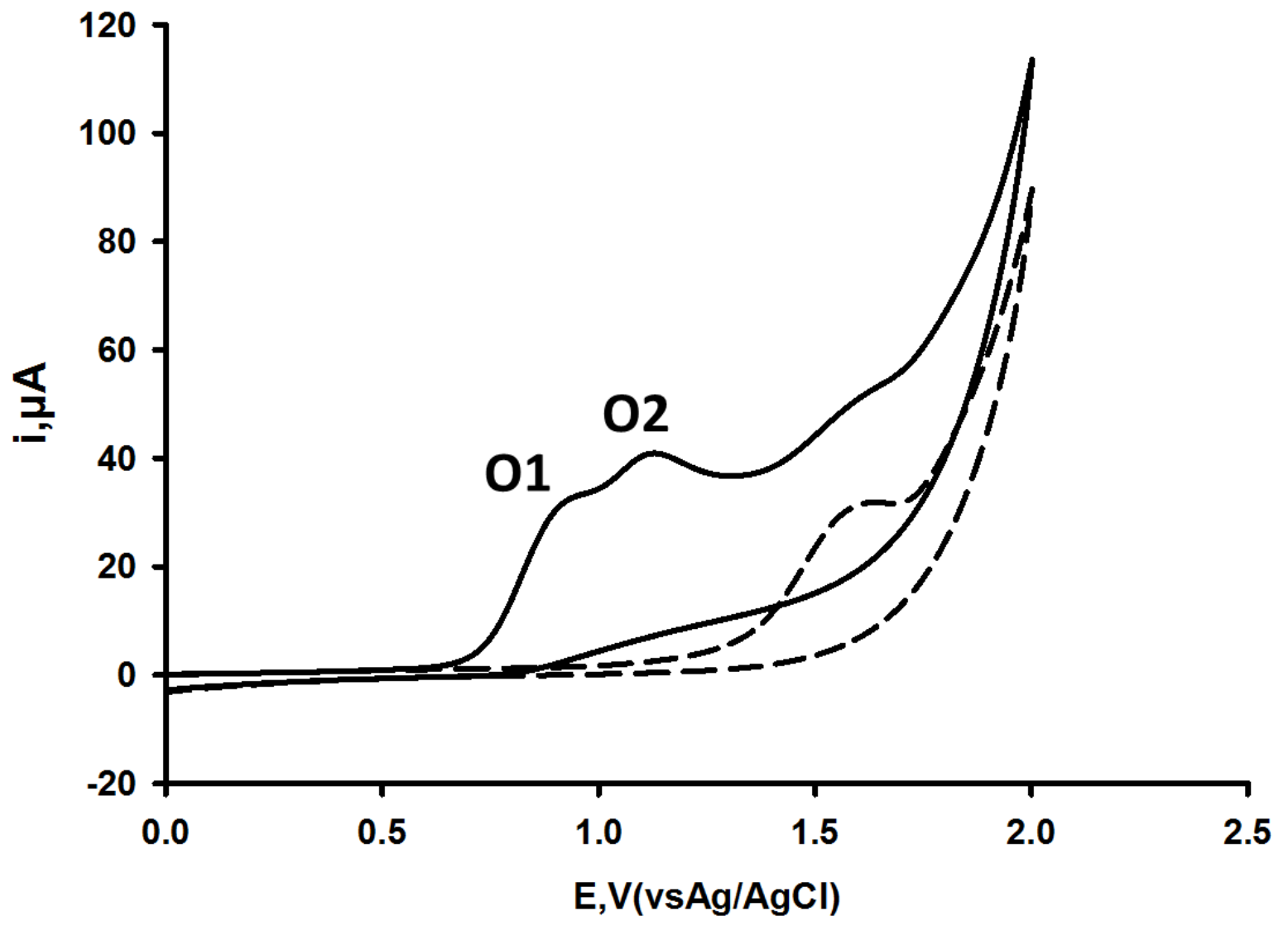

Figure 1. Typical cyclic voltammogram, obtained at a scan rate of $50 \mathrm{mV} / \mathrm{s}$, for dashed line, in the absence of and solid line in the presence of $2 \mathrm{mM}$ nicotine in $10 \%$ acetonitrile, buffered with $0.1 \mathrm{M}$ phosphate at $\mathrm{pH} 10$. Starting potential $0.0 \mathrm{~V}$; switching potential $+2.0 \mathrm{~V}$. 


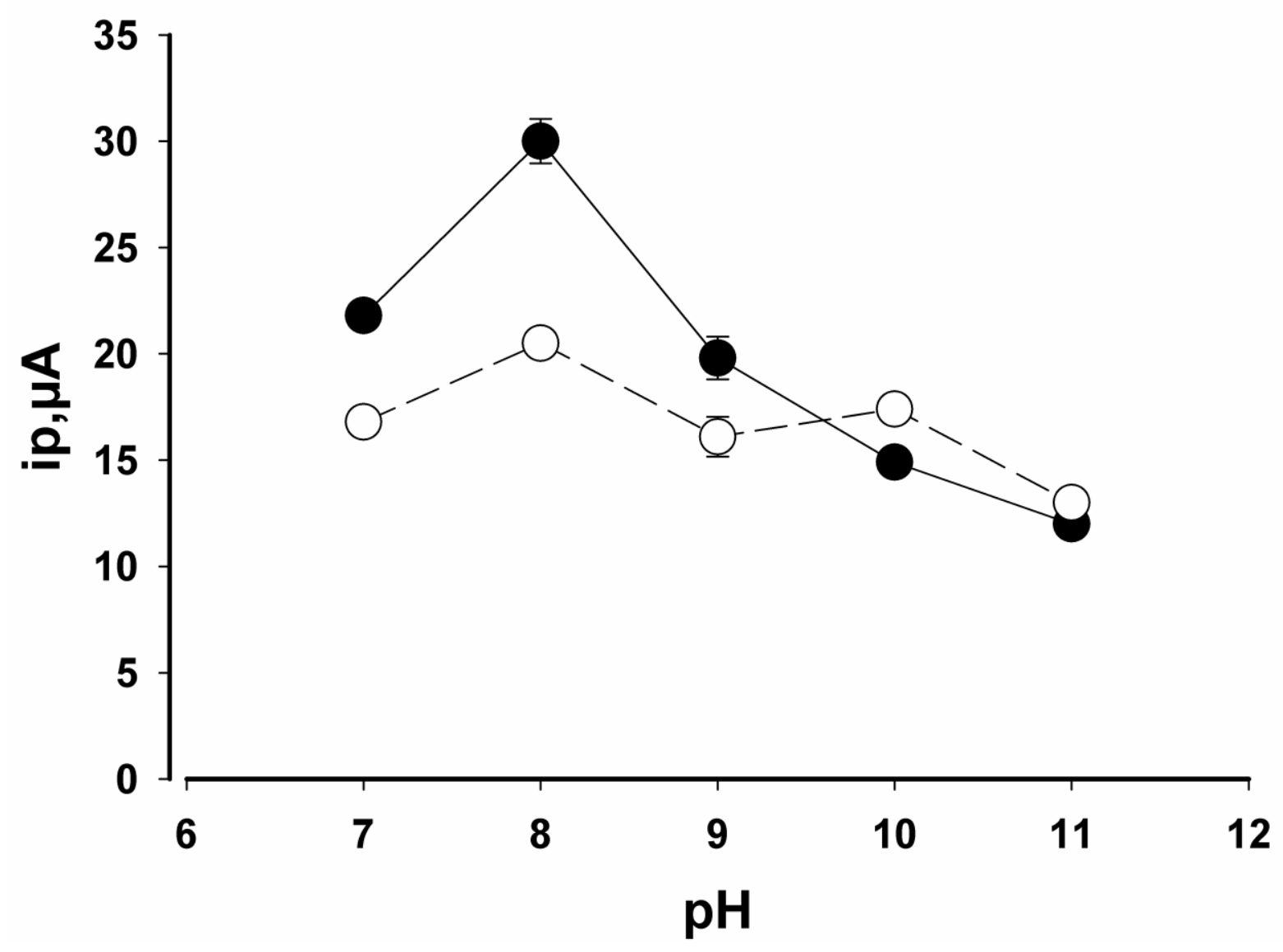

Figure 2. Plot of (a) ip vs. pH for the two nicotine oxidation peaks. Voltammetric conditions as Figure 1. 01 solid line, $\mathrm{O} 2$ dashed line. Error bars represent $\pm \sigma$. 


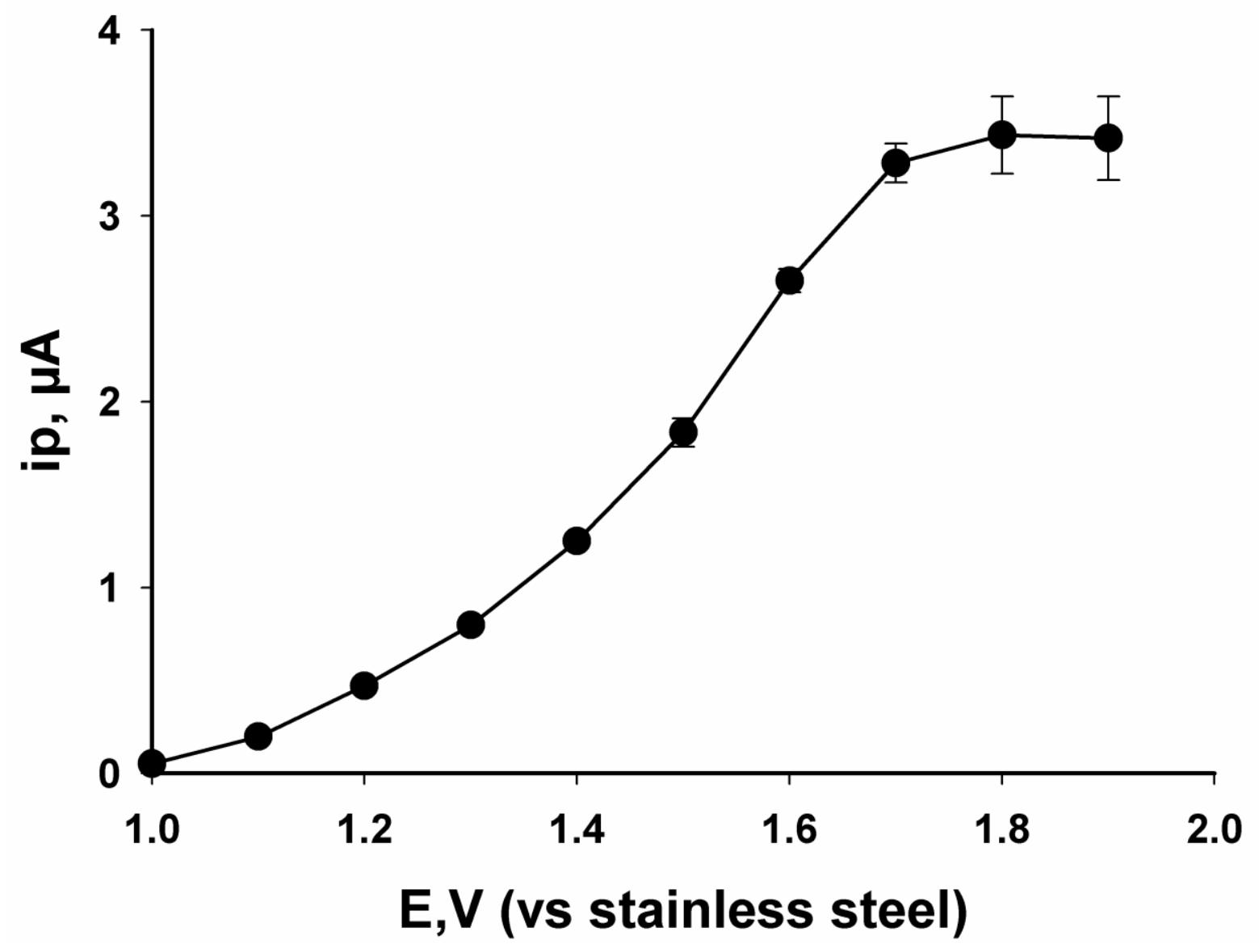

Figure 3. Hydrodynamic voltammogram for $2.6 \mu \mathrm{g}$ injections of nicotine. Error bars represent $\pm \sigma$. 


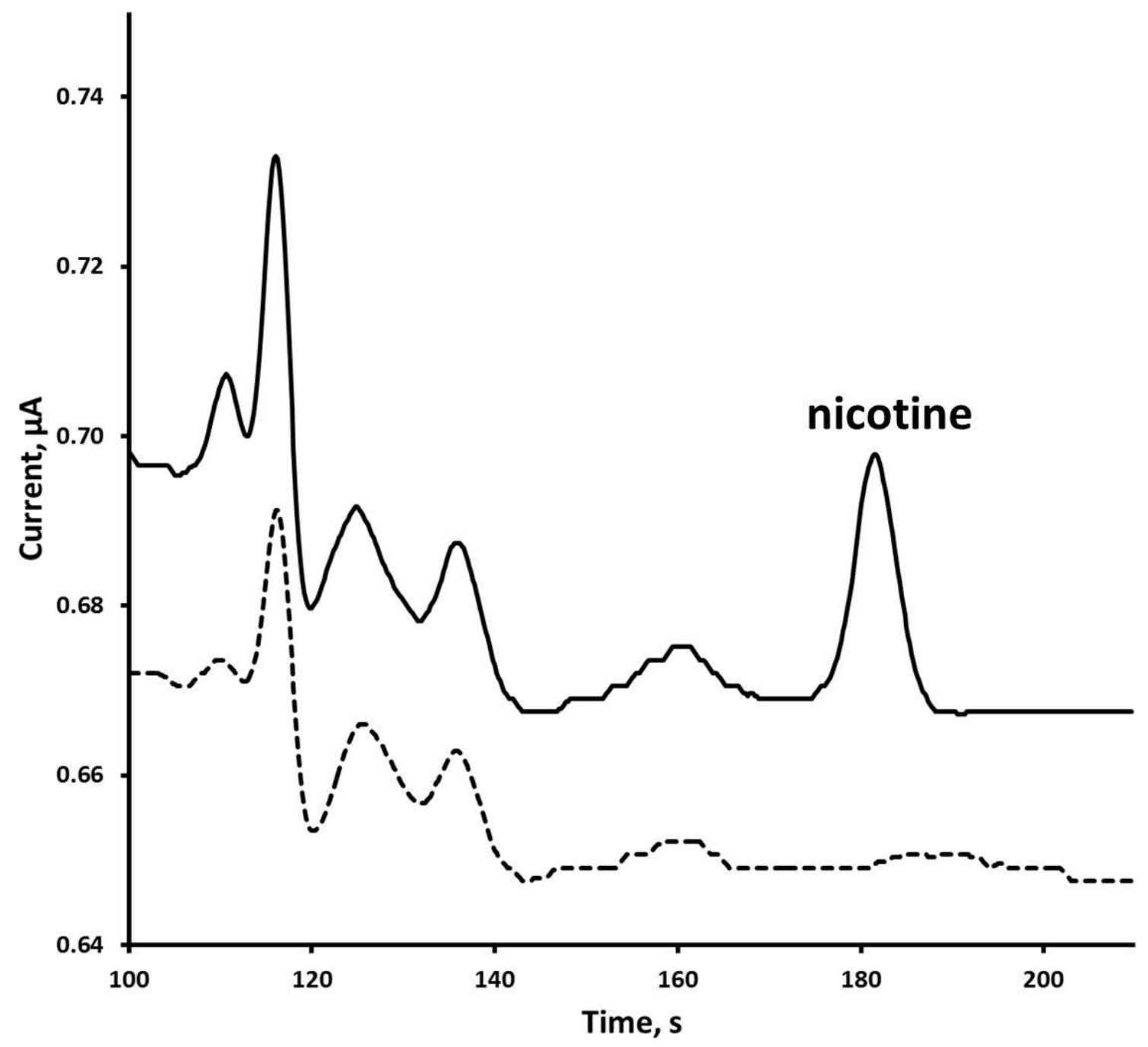

Figure 4. Representative chromatograms obtained for THS dust-wipe samples. Dashed line procedural blank, solid line THS dust wipe sample. 


\section{References}

[1] S. Taghavi, Z. Khashyarmanesh, H. Moalemzadeh-Haghighi, H. Nassirli, P. Eshraghi, N. Jalali, M. Hassanzadeh-Khayyat, Addict. Health, 2012, 4, 28.

[2] IARC (International Agency for Research on Cancer). IARC monographs on the evaluation of the carcinogenic risks to humans - tobacco smoke and involuntary smoking, vol. 83. Available: http://monographs.iarc.fr/ENG/Monographs/vol83/volume83.pdf, 2004. [Accessed: 17/7/14].

[3] S. K. Hammond, B. P. Leaderer, A. C. Roche, M. Schenker, Atmos. Environ. 1987, 21, 457.

[4] C. Feyerabend, M. A. H. Russell, J. Pharm. Pharmacol. 1990, 42, 450.

[5] N. L. Benowitz, The Use of Biologic Fluid Samples In Assessing Tobacco Smoke Consumption, in Measurement in the Analysis and Treatment of Smoking Behavior, NIDA Research Monograph 48, 1983, Editors: J. Grabowski, C.S. Bell, http://ww1.drugabuse.gov/pdf/monographs/48.pdf\#page=17 Accessed 30/6/15.

[6] A. Burton, Environ. Health Perspect. 2011, 119, a70.

[7] M. Sleiman, L. A. Gundel, J. F. Pankow, P. Jacob III, B. C. Singer, H. Destaillats, PNAS, 2010, $107,6576$.

[8] V. Bahl, H. J. Shim, P. Jacob III, K. Dias, S. F. Schickd, P. Talbo, Toxicol. In Vitro, 2016, 32, 220.

[9] G. E. Matt, P. J. E. Quintana, A. L. Fortmann, J. M. Zakarian, V. E. Galaviz, D. A. Chatfield, E. Hoh, M. F. Hovell, C. Winston, Tob. Control 2013, 0:1-9.

[10] N. E. Hood, A. K. Ferketich, E. G. Klein, P. Pirie, M. E. Wewers, Tob. Control 2014, 23, 27.

[11] N. O. F. Kassem, R. M. Daffa, S. Liles, S. R. Jackson, N. O. Kassem, M. A. Younis, S. Mehta, M. Chen, P. Jacob III, S. G. Carmella, D. A. Chatfield, N. L. Benowitz, G. E. Matt, S. S. Hecht, M. F. Hovell, Nicotine Tob. Res. 2014, 16, 961.

[12] J. L. Thomas, S. S. Hecht, X. Luo, X. Ming, J. S. Ahluwalia, S. G. Carmella, Nicotine Tob. Res. 2014, 16, 26.

[13] V. Bahl, P. Jacob III, C. Havel, S. F. Schick, P. Talbot PLoS ONE 2014, 9, e108258. doi:10.1371/journal.pone.0108258

[14] G. E. Matt, P. J. E. Quintana, J. M. Zakarian, A. L. Fortmann, D. A. Chatfield, E. Hoh, A. M. Uribe, M. F. Hovell, Tob. Control, 2010, 20, e1.

[15] J. L. Thomas, H. Guo, S. G. Carmella, S. Balbo, S. Han, A. Davis, A. Yoder, S. E. Murphy, L. C. Ana, J. S. Ahluwalia, S. S. Hecht, Cancer Epidemiol. Biomarkers Prev. 2011, 20, 1213.

[16] G. E. Matt, P. J. E. Quintana, M. F. Hovell, J. T. Bernert, S. Song, N. Novianti, T. Juarez, J. Floro, C. Gehrman, M. Garcia, S. Larson, Tob. Control 2004, 13, 29.

[17] T. Whitehead, C. Metayer, M. H. Ward, M. G. Nishioka, R. Gunier, J. S. Colt, P. Reynolds, S. Selvin, P. Buffler,? Am. J. Epidemiol. 2009, 169, 1113.

[18] T. P. Whitehead, J. R. Nuckols, M. H. Ward, S. M. Emerg. Themes Epidemiol. 2012, 9:2

[19] L. M. Petrick, M. Sleiman, Y. Dubowski, L. A. Gundel, H. Destaillats, Atmos. Environ. 2011, 45, 4959.

[20] P. J. E. Quintana, G. E. Matt, D. Chatfield, J. M. Zakarian, A.L. Fortmann, E. Hoh, Nicotine Tob. Res. 2013, 15, 1555.

[21] V. K. Rehan, R. Sakurai, J. S. Torday, Am. J. Physiol. Lung Cell Mol. Physiol. 2011, 301, L1.

[22] W. K. Al-Delaimy, W. C. Willett, Am. J. Epidemiol. 2011, 173, 822.

[23] W. K. Al-Delaimy, J. Crane, A. Woodward, J. Epidemiol. Community Health 2002, 56, 66.

[24] J. L. Wentzel, J. K. Mulligan, Z. M. Soler, D. R. White, R. J. Schlosser, Am. J. Rhinol. Allergy, 2014, 28, 297.

[25] K. B. Ashford, E. Hahn, L. Hall, M. Kay Rayens, M. Noland, J. E. Ferguson, J. Obstet. Gynecol. Neonatal. Nurs. 2010, 39, 525.

[26] K. B. Ashford, E. Hahn, L. Hall, M. K. Rayens, M. Noland, R. Collins, Nicotine Tob. Res. 2010, 12, 127.

[27] G. N. Mahoney, W. Al-Delaimy, J. Chromatogr. B, 2001, 753, 179. 
[28] R. J. Flanagan, D. Perrett, R. Whelpton, Electrochemical detection in HPLC analysis of drugs and poisons, Vol. 10 of RSC Chromatography Monographs, Royal Society of Chemistry, 2005.

[29] P. T. Kissinger, Electrochemical detection in liquid chromatography and flow injection analysis, in P. T. Kissinger, W. R. Heineman, (ed.) Laboratory techniques in electroanalytical chemistry, Marcel Dekker, New York, 1984 pp. 611-635.

[30] K. Štulík, V. Pacáková, Electroanalytical measurements in flowing liquids, Ellis Horwood, 1987.

[31] P. T. Kissinger, Anal. Chem. 1977, 49, 447A.

[32] S. Mousa, G. R. Van Loon, A. A. Houdi, P. A. Crooks, J. Chromatogr. 1985, 347, 405.

[33] C. Y. Chien, J. N. Diana, P. A. Crooks, J. Pharm. Sci. 1988, 77, 277.

[34] M. -L. Chin-Chena, M. Rambla-Alegrea, A. Durgavanshi, D. Bose, J. Esteve-Romero, J. Chromatogr. B, 2010, 878, 2397.

[35] X. Lin, Y. Sun, D. Xu, Y. Li, S. Liu, Z. Xie, Electrophoresis 2013, 34, 2033.

[36] J. -Y. Sun, X. -Y. Xu, Y. U. Huan, T. -Y. You, Chem. Res. Chinese Universities 2012, 28, 415.

[37] S. Inácia S. e.Silva, P. Bowdler, D. Giltrow, S. Riddell, K. C. Honeychurch, Drug Test. Anal. 2016, in press.

[38] M. Stočes, I. Švancara, Electroanalysis, 2014, 26, 2655.

[39] K. Cinková, L. Dianová, M. Vojs, M. Marton, L. Švorc, Acta Chimica Slovaca, 2015, 8, 166.

[40] H. B. Suffredini, M. C. Santos, D. De Souza, L. Codognoto, P. Homem-de-Mello, K. M. Honório, A. B. F. da Silva, S. A. S. Machado, L. A. Avaca, Anal. Lett. 2005, 38, 1587.

[41] A. Levent, Y. Yardim, Z. Senturk, Electrochim. Acta 2009, 55, 190.

[42] H. Kassa, A. Geto, S. Admassie, Bull. Chem. Soc. Ethiop. 2013, 27, 321.

[43] J. Grimshaw, Electrochemical Reactions and Mechanisms in Organic Chemistry, p. 36, Elsevier, Amsterdam, 2000. 